TID-4500 D1stribution, UC-13 Nonnuclear Energy Sources and

Energy Conversion Devices

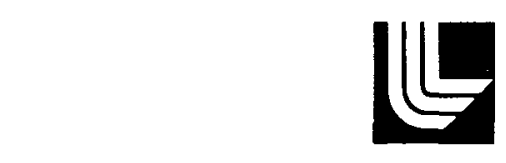

LAWRENCE LVERMORE LABORATORY

University of Caftornia/Livermore, Calitomia/94550

UCRL -51747

\title{
ANALYSIS OF POTENTIAL NONELECTRICAL APPLICATIONS OF GEOTHERMAL ENERGY AND THEIR PLACE IN THE NATIONAL ECONOMY
}

Gordon M. Reistad

MS. date: February 14, 1975

This report was prepared as an account of work
sponsored by the United States Government. Neither
the United States nor the United States Energy
Research and Development Administration, nor any of
their employees, nor any of their contractors,
subcontractors, or their employees, makes any
warranty, express or implied, or assumes any legal
lability or responsibility for the accuracy, completeness
or usefulness of any information, apparatus, product or
process disclosed, or represents that its use would not
infringe privately owned rights.

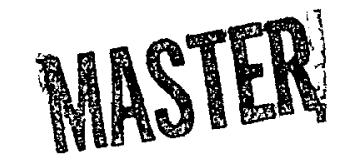




\section{DISCLAIMER}

This report was prepared as an account of work sponsored by an agency of the United States Government. Neither the United States Government nor any agency Thereof, nor any of their employees, makes any warranty, express or implied, or assumes any legal liability or responsibility for the accuracy, completeness, or usefulness of any information, apparatus, product, or process disclosed, or represents that its use would not infringe privately owned rights. Reference herein to any specific commercial product, process, or service by trade name, trademark, manufacturer, or otherwise does not necessarily constitute or imply its endorsement, recommendation, or favoring by the United States Government or any agency thereof. The views and opinions of authors expressed herein do not necessarily state or reflect those of the United States Government or any agency thereof. 


\section{DISCLAIMER}

Portions of this document may be illegible in electronic image products. Images are produced from the best available original document. 


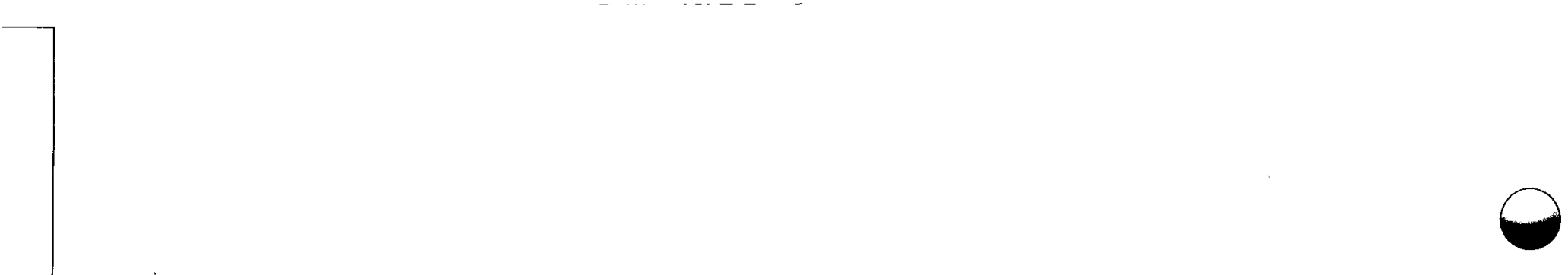




\section{Contents}

Abstract . . . . . . . . . . . . . . . . . . . . . . . . . . . . . 1

Introduction . . . . . . . . . . . . . . . . . . . . . 1

Large Uses of Geothermal Energy . . . . . . . . . . . . . . . . . . . . . . . . . . . 2

Temperature Limit for Nonelectrical Applications . . . . . . . . . . . . . . . . . . . . 2

Potential Nonelectrical Applications in the United States . . . . . . . . . . . . . . . . . . 2

Space Heating . . . . . . . . . . . . . . . . . . . . . . . . . . . . . . . . 2

Water Heating . . . . . . . . . . . . . . . . . . . . . . . . . . . . . . . . 2

Air Conditioning . . . . . . . . . . . . . . . . . . . . . . . . . . . . . . . 4

Refrigeration ........................ . . 4

Cooking . . . . . . . . . . . . . . . . . . . . . 4

Clothes Drying . . . . . . . . . . . . . . . . . . . . . . . 4

Transportation, Nonenergy, and Electrolysis . . . . . . . . . . . . . . . . . 5

Direct Heat, Electric Drives, and Process Steam . . . . . . . . . . . . . . . . . . . 5

Other Uses . . . . . . . . . . . . . . . . . . . . . . . . . . . . . . . . . 10

Discussion and Summary . . . . . . . . . . . . . . . . . . . . . . . . . . . . . 13

Energy-Cost-Intensive Industrial Uses of Geothermal Energy . . . . . . . . . . . . . . . . . . 17

Steam Requirements in Selected Industrial Processes . . . . . . . . . . . . . . . . . . . 17

Acetic Acid from Wood Via Suida Process . . . . . . . . . . . . . . . . . . . . . 17

Ethyl Alcohol from Sulphite Liquors . . . . . . . . . . . . . . . . . . . . . . . 19

Lactose Production . . . . . . . . . . . . . . . . . . . . . . . . . . . . . . 19

Ethyl Alcohol from Wood Waste . . . . . . . . . . . . . . . . . . . . . . . . . 19

Aluminum Sulphate Production . . . . . . . . . . . . . . . . . . . . . . . . . 20

Summary . . . . . . . . . . . . . . . . . . . . . . . 20

Conclusion . . . . . . . . . . . . . . . . . . . . . . . . 21

References . . . . . . . . . . . . . . . . . . . . . . 22

Appendix: Major Applications of Geothermal Energy in the Chemical and Allied Products Industries . . 23 


\begin{abstract}
This work considers two aspects of evaluating the potential for nonelectrical utilization of geothermal resources. First, the U.S. is considered as an example and its energy consumption requirements are analyzed to determine in what ways and to what extent geothermal energy can be effectively applied. The evaluation is limited to potential uses having energy requirements at temperatures less than $250^{\circ} \mathrm{C}$, which here is considered to be the desirable maximum temperature for direct application of geothermal energy. The study

is further constrained by assuming that an appropriate geothermal resource is available at each potential application site. On this basis, greater than $40 \%$ of all U.S. energy requirements could be supplied by geothermal energy at temperatures less than $200^{\circ} \mathrm{C}$. Second, an evaluation is made of the energy-cost intensiveness of a number of steam-consuming industrial processes. Then, the ten most energy-cost-intensive industrial processes are further evaluated as potential consumers of geothermal energy.
\end{abstract}

\title{
Introduction
}

Much of the current interest in geothermal energy is directed toward its use in electricity generation. However, potential nonelectrical applications for this energy resource should also be considered. This report examines the present status and future prospects of nonelectrical uses of geothermal energy in the U.S. This work* is part of a larger, international study on the subject sponsored by the North Atlantic Treaty Organization through its Committee on the Challenges of Modern Society (CCMS).

In evaluating the merit of a national research effort aimed at developing nonelectrical uses of geothermal energy, four major questions regarding potential must be answered:

- Do potential nonelectrical users of geothermal energy account for a significant portion of the total energy consumed in this country?

- Is the energy-cost-per-dollar value of products produced by industrial potential users high enough to motivate them to reinvest in equipment, relocate, and/or develop new processing methods to allow utilization of geothermal energy?

- What geothermal resources (size, temperature, impurities, etc.) exist in the U.S.?

- How well do the locations of these geothermal resources match the locations of significant potential users?

This study examines the first two questions only. The latter two questions, while fundamentally important, are not considered here. In reference to the questions addressed, the report is divided in to two major sections:

- Large Uses of Geothermal Energy - On a nationwide basis, what potential geothermal uses are of significant magnitude and how large is the total geothermal potential in relation to overall U.S. energy use?

- Energy-Cost-Intensive Uses of Geothermal Energy - What potential industrial geothermal uses have energy costs as a significant part of their total cost?
*This work was done under the supervision of Dr.J.H. Howard while the author was on summer appointment to the Lawrence Livermore Laboratory. Dr. Howard is chairman of the CCMS subcommittee charged with preparing the international report on nonelectrical uses of geothermal energy. In addition to having editorial responsibility for the overall CCMS report, Dr. Howard heads the U.S. contribution to the document. 


\section{Large Uses of Geothermal Energy}

Here, potential nonelectrical applications of geothermal energy that could be significant on a national scale are considered. In this analysis, the U.S. is used as an example. An examination is made of total U.S. energy consumption to determine where and how present energy sources can be replaced with geothermal energy, assuming in each case that adequate geothermal resources are available at the site.

\section{TEMPERATURE LIMIT FOR NONELECTRICAL APPLICATIONS}

The lower end of the temperature range for heating by geothermal energy is limited by the temperature of the natural environment in the inhabited parts of the earth (about -35 to $+45^{\circ} \mathrm{C}$ ). At temperatures below that of the natural surroundings, heating can be accomplished by energy exchange with the environment and geothermal energy is not required.* At temperatures above the natural environment, geothermal energy can be used for heating, as long as the required temperature is less than that of the geothermal resource. However, because of the desirability of electrical energy, if electricity can be generated economically using a given geothermal resource, the main resource probably will not be available for nonelectrical processes. Generating electricity from geothermal water at $200^{\circ} \mathrm{C}$ or less quite often is not economical because of very low efficiencies (less than 7\%) and very large specific flow rates (greater than a million pounds per hour). There is much uncertainty, however, regarding the exact temperature at which geothermal electricity generation becomes economical. Because of this uncertainty and to ensure that all realistically potential nonelectrical uses of geothermal energy are considered, $250^{\circ} \mathrm{C}$ is deemed to be the maximum temperature for direct application of geothermal energy.

\section{POTENTIAL NONELECTRICAL APPLICATIONS IN THE UNITED STATES}

Figure 1 shows energy flow in the U.S. during 1968.* On the right side of this flowchart, the specific energyuse categories are classified as "Potential Geothermal Use" or "Nongeothermal Use." In the following subsections, each energy-use category is discussed and reasons are given for its geothermal classification.

\section{Space Heating}

Residential and commercial space heating accounted for $10,857 \times 10^{12} \mathrm{Btu}$ in 1968 , roughly $18 \%$ of total U.S. fuel consumption that year. Space heating could be a very large use for geothermal energy since the minimum temperature that could be used in a direct heating system need only be about $40^{\circ} \mathrm{C}$, with usual practice being more in the $60-$ to $-90^{\circ} \mathrm{C}$ range.

\section{Water Heating}

Water heating in the residential and commercial sectors consumed $2,389 \times 10^{12}$ Btu in 1968 , about $4 \%$ of all energy used in the U.S. that year. Again, temperature requirements for water heating are well within the range of geothermal energy capability. For residential use, which accounts for 3 of the $4 \%$, domestic hot water is conventionally heated to a maximum of about $70^{\circ} \mathrm{C}$. Thus, geothermal water of 80 to $90^{\circ} \mathrm{C}$ would be quite practical, since counterflow heating would allow the geothermal water to cool substantially below $70^{\circ} \mathrm{C}$ thereby providing reasonable flow rates. In commercial applications, the average required maximum temperature is probably somewhat higher, reaching values of perhaps $85^{\circ} \mathrm{C}$. Here, geothermal water between 95 and $100^{\circ} \mathrm{C}$ would be required for practical operation.
${ }^{*}$ Cooling at temperatures below the natural environment would require some type of refrigeration. It could be accomplished using geothermal energy via an absorption-refrigeration system. With present systems of this type, outside temperature could not be less than $-77^{\circ} \mathrm{C}$ (freezing point of ammonia) and, at temperatures below $-33^{\circ} \mathrm{C}$, the ammonia would have to be in vacuum.

\footnotetext{
*The 1968 data were used because they were the latest available in a form convenient for this analysis. (These data had been analyzed in 1972 by Stanford Research Institute.) Moreover, the author felt that the same trends exhibited in the 1968 data would also appear in more recent information.
} 


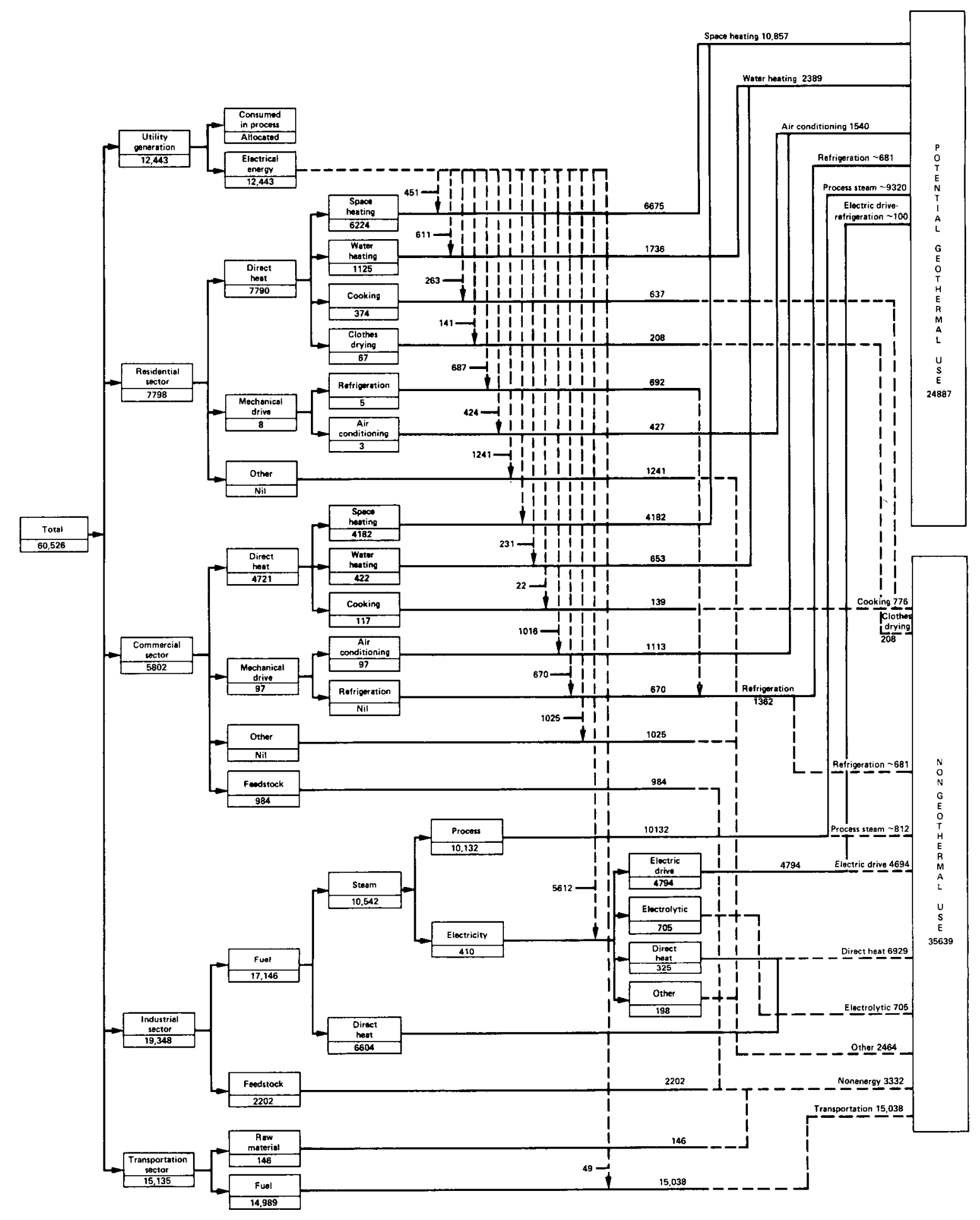

Fig. 1. Potential nonelectrical use of geothermal energy in the U.S. Numbers indicate energy use in trillions of Btu based on 1968 data. Data source: Stanford Research Institute, Patterns of Energy Consumption in the United States (1972). 


\section{Air Conditioning}

In 1968 , residential and commercial air conditioning used $1540 \times 10^{12} \mathrm{Btu}(2.5 \%$ of total 1968 U.S. energy consumption). Air conditioning holds substantial potential for using geothermal energy through an already well developed process: absorption air conditioning. Commercial- and residential-size units are readily available. The two currently practical systems operate on either an ammonia-water or a water-lithium-bromide cycle. The water-lithium-bromide system is the more popular of the two because it is simpler, performs better, and does not have the disadvantage of using ammonia, a strong irritant, mildly toxic, combustible substance. The water-lithium-bromide system, which typically operates at heating temperatures of 95 to $120^{\circ} \mathrm{C}$, would require geo thermal water ranging from 110 to $135^{\circ} \mathrm{C}$.

Residential applications generally use ammoniawater systems because these units can be air cooled, thereby eliminating the need for a cooling tower. The units must be located outside, however, because of the hazardous properties of ammonia. Also, this system would require higher geothermal temperatures (150 to $200^{\circ} \mathrm{C}$ ).

\section{Refrigeration}

Refrigeration in the U.S. in 1968 accounted for $692 \times 10^{12}$ Btu of the energy used in the residential sector, $670 \times 10^{12} \mathrm{Btu}$ in the commercial sector, and a sizeable amount in the industrial sector. (The industrial amount is indeterminate, but is contained in the "electric drives" category of Fig. 1.) Most refrigeration requires temperatures near or below $0^{\circ} \mathrm{C}$, so the refrigerant usually must operate below $0^{\circ} \mathrm{C}$. Thus, the water-lithium-bromide absorption air conditioning system is not applicable for most refrigeration tasks because the refrigerant (water) cannot operate below $0^{\circ} \mathrm{C}$. The ammonia-water system, on the other hand, can operate below $0^{\circ} \mathrm{C}$ and is the likely candidate for most geothermally driven refrigeration applications. For good performance, heating temperature must be 150 to $200^{\circ} \mathrm{C}$. This system can be used quite readily for large industrial and commercial applications, but its practicality for residential and smaller industrial and commercial applications remains to be shown.

As noted previously, one problem with the ammoniawater system is the hazardous properties of ammonia. For this reason, its use is somewhat restricted. The trend has been to use it only in large installations where there is full-time monitoring of the system, when the unit can be placed outdoors, or when the total amount of ammonia required is small enough not to pose a problem. For residential applications, the amount of ammonia required for refrigeration is small enough to permit use of the ammonia-water system. However, in a commercial situation requiring substantial refrigeration but not having a full time supervisor, the ammoniawater system probably is not suitable.

All residential-size absorption refrigerators manufactured and marketed to date have been direct-fired units. In the 1960 s direct-fired ammonia-water systems for residential applications were marketed in the U.S., but could not compete economically with electric-driven units. Presently, some direct-fired systems using ammonia, water, and hydrogen are being used in the U.S., primarily for applications where electricity is not available (e.g., recreational vehicles). This ammoniawater-hydrogen system has the advantage of simplicity over the pure ammonia-water system and does not require a pump, but it has the disadvantage of poorer performance (only about half as good as the pure ammoniawater system).

Based on the above discussion, it is estimated that about half of the commercial and residential refrigeration needs could be satisfied by geothermally driven refrigeration systems. Industrial refrigeration requirements are considered in the "Direct Heat, Electric Drives, and Process Steam" section.

\section{Cooking}

Cooking consumed $776 \times 10^{12} \mathrm{Btu}$, or about $1.3 \%$ of total U.S. energy use in 1968. Although cooking represents a sizeable fuel usage and its temperature requirement is less than $250^{\circ} \mathrm{C}$, it is classified as a nongeothermal use because it is an intermittent use, requires fast response from very high temperatures, and, except for some commercial applications, would require completely new appliance designs. Although geothermal energy conceivably could be used for cooking, the savings in fuel does not appear to justify the complexity and degree of effort that would be required.

\section{Clothes Drying}

Clothes drying consumed $208 \times 10^{\mathbf{1 2}} \mathrm{Btu}$, or about $0.33 \%$ of all energy used in the U.S. during 1968. As

. 
with cooking, however, geothermal energy could be used for drying clothes, but the fuel savings probably would not justify the complexity and magnitude of effort required.

Transportation, Nonenergy Uses of Fuels, and Electrolysis

Energy requirements in these areas cannot be directly satisfied by geothermal energy.

Direct Heat, Electric Drives, and Process Steam

These are all industrial energy uses, having a variety of specific characteristics. Together they represented $21,855 \times 10^{12} \mathrm{Btu}$, or $36 \%$ of total U.S. fuel consumption in 1968. To justify the classification of these energy uses into potential geothermal or nongeothermal categories (see Fig. 1), requires an analysis of the industrial sector to determine:

- How much process steam could be generated by geothermal energy having temperatures below $250^{\circ} \mathrm{C}$;

- How much of the fuel used in direct heating could be saved by using geothermal heating;

- How much of the fuel used to operate electric drives could be saved by using geothermally generated refrigeration for industrial processes.

Figure 2 shows energy flow through the industrial sector and energy consumption by "feedstock," "direct heat," "process steam," "electric drives," "electrolysis," and "other electricity" in the major energy-consuming industries, with the remainder lumped in to "all other industries." Let us first consider the nature of the energy use in each of the major industries and then try to classify the "direct heat," "process steam," and "electric drive" categories into potential geothermal uses or nongeothermal uses.

Primary Metals - The primary metals sector of the economy is characterized by high-grade energy use (e.g., heating at very high temperatures and electricity for drives and electrolysis). Some steam is generated, but it is used primarily for mechanical drives or electricity generation. Although metallurgical plants make great use of refrigeration, energy use for refrigeration in the primary metals industry appears to be quite small relative to total energy use in the industry. The potential for direct use of geothermal energy in the primary metals industry is quite small.
Chemical and Allied Products - This sector has a myriad of potential geothermal energy applications, the largest energy consumers of which are given in Table 1. The applications listed in Table 1 accounted for $2667 \times 10^{12}$ Btu of the total $4017 \times 10^{12}$ Btu consumed in this sector during 1967. However, they used only $852 \times 10^{12} \mathrm{Btu}$ of the total $2202 \times 10^{12} \mathrm{Btu}$ consumed for purposes other than feedstock. Although these industries did not use a majority of the energy consumed for other-than-feedstock purposes, it is assumed that Table 1 lists only large energy users and that the remaining energy consumption is due to many small, diverse users. These small users will not be considered further in this report. Each of the major applications (chlorine-caustic soda, synthetic soda ash, ammonia, alumina, methanol and sulfur by the Frasch method) are discussed in greater detail in Appendix A. Of these, the ammonia and methanol processes require temperatures above $250^{\circ} \mathrm{C}$ and have little potential for direct use of geothermal energy. The other processes could use geothermal energy directly at temperatures below $250^{\circ} \mathrm{C}$ in amounts estimated at: $69 \times 10^{12}$ Btu for the chlorine-caustic soda industry, $57 \times 10^{12}$ Btu for the synthetic soda ash industry, $52 \times 10^{12} \mathrm{Btu}$ for the alumina industry, and $60 \times 10^{12}$ Btu for Frasch-method sulfur mining.

Petroleum - In the petroleum industry, energy is used largely to convert crude oil into usable energy forms. About $11 \%$ of the total energy input to a refinery is used in conversion processes. As indicated in Fig. 2, the bulk of energy consumption in this sector (about $60 \%$ ) is for direct heat, largely in the form of fuel to operate oil- and gas-fired heaters. For example, process steam is heated to leaving temperatures of about $375,475,500$, and $500^{\circ} \mathrm{C}$ for the crude, viscosity-breaking, reforming, and distilled-oil heaters, respectively. These end temperatures, higher than achievable with geothermal resources, largely preclude the use of geothermal energy.

Process stean accounts for about $34 \%$ of the total energy consumed in the petroleum sector. Petroleum refineries generally have a central plant that supplies steam and may or may not also generate electric power. The steam, either directly from steam generators or from the exhaust of electric-generator turbines, is used to power mechanical drives and to provide process heat and process steam throughout the refinery. Although some of this steam is required at temperatures 


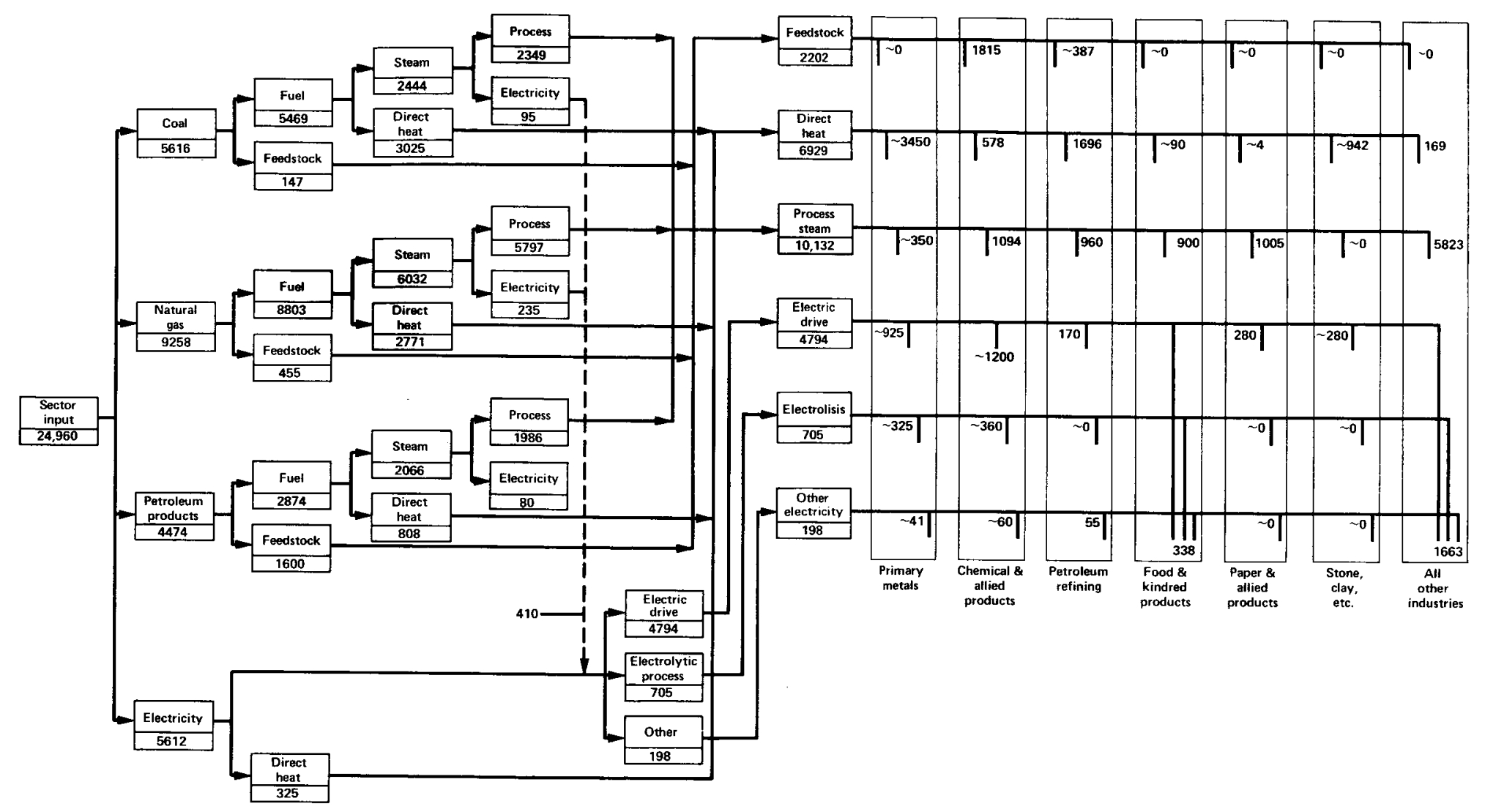

Fig. 2. Breakdown of energy use by energy types for major U.S. industries. Numbers indicate energy use in trillions of Btu based on 1968 data. Data source: Stanford Research Institute, Patterns of Energy Consumption in the United States (1972). 
Table 1. Energy consumption by end use in the chemical industry $\left(10^{12} \mathrm{Btu}, 1967 \mathrm{data}\right){ }^{\mathrm{a}}$

\begin{tabular}{|c|c|c|c|c|c|c|c|c|c|c|c|c|c|c|}
\hline & \multicolumn{3}{|c|}{ Space heating } & \multicolumn{3}{|c|}{ Process heat } & \multicolumn{3}{|c|}{ Mechanical drive } & \multicolumn{3}{|c|}{ Electrical uses ${ }^{b}$} & \multirow[b]{2}{*}{ Total } & \multirow[b]{2}{*}{ Feedstock } \\
\hline & Fuel & Steam & Electric & Fuel & Steam & Electric & Fuel & Steam & Electric & Lighting & Electrolysis & Other & & \\
\hline Chlorine - caustic soda & - & - & - & - & 69 & - & - & - & -1 & $\mathrm{c}$ & 80 & - & 150 & - \\
\hline Soda ash (synthetic) & - & - & - & 124 & 57 & - & - & - & Negl & Negl & - & - & 181 & - \\
\hline $\begin{array}{l}\text { Acetylene (hydrocarbon } \\
\text { source) }\end{array}$ & - & - & - & - & 9 & - & - & - & 1 & Negl & - & - & 10 & 45 \\
\hline Oxygen & - & - & - & - & - & - & - & 36 & 13 & Negl & - & - & 49 & - \\
\hline Carbon black & - & - & - & 4 & - & - & - & - & - & $\mathrm{Negl}$ & - & - & 4 & 212 \\
\hline Ammonia & - & - & - & 85 & 113 & - & - & - & 2 & Negl & - & - & 200 & 299 \\
\hline $\begin{array}{l}\text { Aluminum oxide (ex- } \\
\text { cluding natural) }\end{array}$ & - & - & - & 24 & 52 & - & - & - & 1 & Negl & - & - & 77 & - \\
\hline Phosphorus & - & - & - & 1 & - & - & - & - & & & 26 & - & 27 & 20 \\
\hline Methanol & - & - & - & 13 & 13 & - & - & - & 1 & & - & - & 27 & 39 \\
\hline Sulfur (frasch) & - & - & - & 72 & - & - & - & - & - & & - & - & 72 & - \\
\hline $\begin{array}{l}\text { Ethylene, propylene, } \\
\text { butadiene, aromatics } \\
\mathrm{C}_{2}, \mathrm{C}_{3} \text {, and } \mathrm{C}_{4}\end{array}$ & - & - & - & 5 & 25 & - & - & - & 5 & & - & - & 35 & 1,200 \\
\hline Subtotal & & & & $\overline{328}$ & $\overline{338}$ & & & $\overrightarrow{36}$ & $\overline{24}$ & & $\overline{106}$ & & $\overline{832}$ & $\overline{1,815}$ \\
\hline \multirow[t]{2}{*}{ Space heating } & \multirow{2}{*}{\multicolumn{3}{|c|}{$-20-$}} & & & & & & & & & & 20 & - \\
\hline & & & & & & & & & & & & & 852 & 1,815 \\
\hline Balance of industry & \multicolumn{2}{|c|}{$-60-$} & & 170 & 500 & - & & $220^{\mathrm{d}}$ & 367 & $21^{e}$ & 12 & & 1,350 & - \\
\hline Industry total & \multicolumn{2}{|c|}{$-80^{f}-$} & & 498 & 838 & & & 256 & 391 & 21 & 118 & & 2,202 & 1,815 \\
\hline
\end{tabular}

${ }^{a}$ Source: Stanford Research Institute, Patterns of Energy Consumption in the United States (1972).

$\mathrm{b}_{1 \mathrm{kWh}}=3,413 \mathrm{Btu}$.

${ }^{\mathrm{c}}$ Included in electrolytic load.

${ }^{d}$ Energy used for electrical generation highly integrated with process steam production.

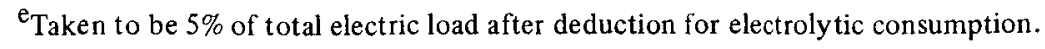

${ }^{\mathrm{f}}$ Taken to be $5 \%$ of total direct and steam input. 
exceeding $400^{\circ} \mathrm{C}$, more than about $80 \%$ of it is used at steam saturation temperatures of $180^{\circ} \mathrm{C}$ or less. ${ }^{2}$

The potential for geothermal application in petroleum refining, largely contingent on the need for process steam, is estimated to be $960 \times 10^{12}$ Btu per year. Two factors contribute to this estimate. First, it appears that most of the process steam applications (80 to 90\%) can be satisfied by geothermal energy at temperatures less than $250^{\circ} \mathrm{C}$, but some uses of process steam require much higher temperatures that cannot be achieved with geothermal energy. Second, there appears to be some potential for using small amounts of geothermal energy for preheating purposes in direct-heat processes. This probably would be less than $10 \%$ of all direct-heat energy needs.

Food and Kindred Industries - The major energy-using processes in this sector are listed in Table 2 with their respective energy-consumption values. Except for the bakery industry, energy requirements in this area are primarily for mechanical drives, relatively low-

temperature heating (which could be accomplished with steam at pressures less than $50 \mathrm{psig}$ ), and refrigeration (which could be supplied by absorption refrigeration).

Process steam usage has been estimated to be $10 \%$ at pressures between 50 and 100 psig and $90 \%$ at pressures less than 50 psig. $^{2}$ Based on general refrigeration activities in the meat, dairy, frozen food, and beverage industries, an estimated 10 to $30 \%$ of the electricity now used for refrigeration (roughly $50 \times 10^{12} \mathrm{Btu}$ ) could be replaced with geothermal absorption refrigeration. Thus, geothermal energy could provide about $950 \times 10^{12}$ Btu of the yearly $1328 \times 10^{12}$ Btu consumed in this sector.

Paper and Allied Products - Energy in a pulp and paper mill typically is consumed in two forms: steam and electric power. Figure 3 shows the estimated

Table 2. Energy consumption in food and kindred product industries $\left(10^{12} \mathrm{Btu}, 1967 \mathrm{data}\right) .^{\mathrm{a}}$

\begin{tabular}{|c|c|c|c|c|c|}
\hline Category & $\mathrm{Coal}^{\mathrm{b}}$ & $\mathrm{Oil}^{\mathrm{b}}$ & $\mathrm{Gas}^{\mathrm{b}}$ & Electricity ${ }^{b}$ & Totals \\
\hline Meat & 15.7 & 11.9 & 48.0 & 37.2 & 112.8 \\
\hline Dairy products & 12.2 & 13.8 & 45.1 & 31.8 & 102.9 \\
\hline Canned and frozen foods & 8.4 & 9.6 & 39.1 & 24.5 & 81.6 \\
\hline Grain mills & 45.6 & 4.3 & 38.6 & 38.6 & 127.1 \\
\hline Bakery products & 0.3 & 8.7 & 27.7 & 17.1 & 53.8 \\
\hline Sugar & 26.5 & 11.5 & 58.4 & 11.4 & 107.8 \\
\hline Candy & 1.5 & 3.3 & 4.8 & 9.0 & 18.6 \\
\hline Beverages & 25.7 & 13.0 & 34.7 & 20.4 & 93.8 \\
\hline Miscellaneous & 25.9 & 15.0 & 49.6 & 25.3 & 115.8 \\
\hline Totals & 161.8 & 91.1 & 346.0 & 215.3 & 814.2 \\
\hline
\end{tabular}

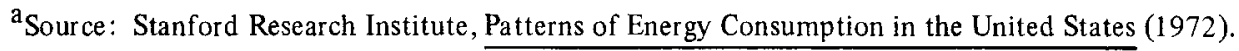

${ }^{\mathrm{b}}$ Factors used: 26.2 million Btu per short ton of coal 6.0 million Btu per barrel (42 gallons) of oil 1,035 Btu per cubic foot of gas 9,250 Btu per kwh.
} 


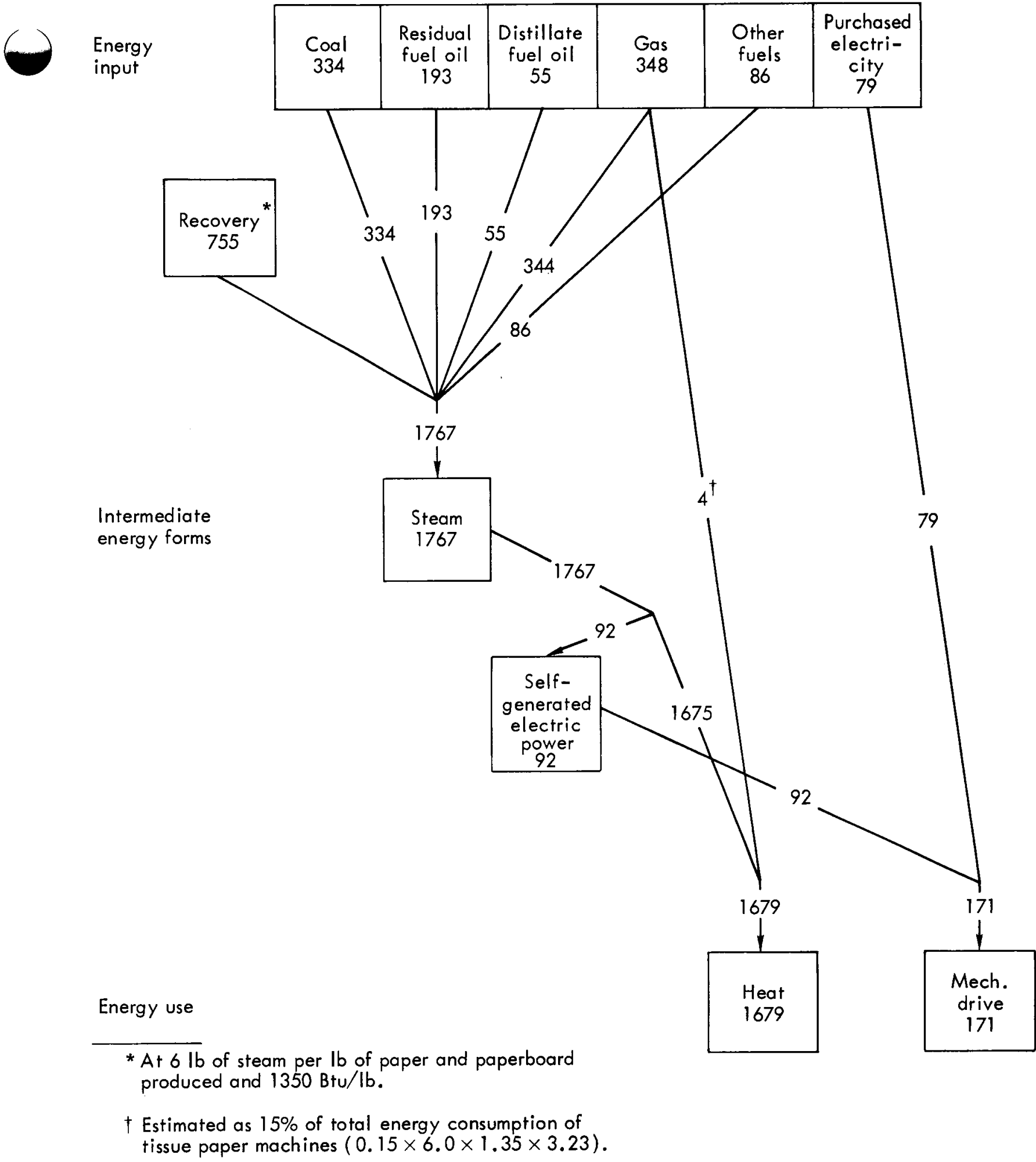

Fig. 3. Estimated energy flow in the manufacture of paper and allied products. Numbers indicate energy use in trillions of Btu based on 1967 data. Source: Stanford Research Institute, Patterns of Energy Consumption in the United States (1972). 
energy flow in manufacturing paper and allied products. Of the total energy use, 10 to $15 \%$ is electricity for mechanical drives, some of which may be generated in-plant via recovery boilers. The remainder of the total energy requirement is for heating, generally by steam at pressures up to about 165 psig. Most of the steam requirements, however, are at lower pressures (50 to $125 \mathrm{psig}$ ). Because all of the steam requirements can be met geothermally and the electricity requirement is quite low in relation to the steam requirements, the prospect for using geothermal energy in this industry is quite good.

Stone, Clay, Glass and Concrete Products - These industries are characterized by energy use at very high temperatures. Although dry-process cement plants need some thermal energy slightly above $100^{\circ} \mathrm{C}$ for drying the clay before processing, the bulk of the energy requirement is for direct firing of the kilns. The clay industry is very similar to the cement industry in that almost all of the energy need is for firing kilns. Almost all glass-industry energy requirements are for heating at temperatures greater than $500^{\circ} \mathrm{C}$. Thus, there appears to be little potential for direct application of geothermal energy in this group of industries.

Other Industries - This category includes Standard Industrial Classification (SIC)* groups: 21, 22, 23, $24,25,27,30,31,34,35,36,37,38$, and 39. (See Table 3 for SIC classifications 20 through 39).*

Energy use in these sectors constitute about $30 \%$ of all industrial energy consumption in this country. The large amount of process steam here (see Fig. 2) appears somewhat out of place because these industries, except for the textile and rubber and plastic industries, generally are not considered to be large process steam consumers. The overly large amount may be somewhat explained by the fact that the process steam classification is a catchall category, in that it includes a large part of the industrial space heating (amounting to possibly $1200 \times 10^{12} \mathrm{Btu}$ ) and other miscellaneous heating operations whether or not the heating is by steam. For purposes here, since time constraints prevent an analysis of this classification of use, the
$5823 \times 10^{12}$ Btu consumed as process steam is assumed to consist of $1200 \times 10^{12} \mathrm{Btu}$ of industrial space heating and $4623 \times 10^{12}$ Btu of steam consumption that follows the same pattern of use as the combination of the industries considered in the previous sections.

Estimated Potentials for Geothermal Applications Direct heat applications are mostly fuel combusted in process applications or heating at very high temperatures, substantially higher than the $250^{\circ} \mathrm{C}$ limit selected here for potential geothermal applications. Hence, essentially none of the fuel consumed as "direct heat" can be replaced by geothermal energy.

Electric drive applications in the industrial sector amount to $4794 \times 10^{12} \mathrm{Btu}$, including refrigeration. The only major sector devoting a significant part of its total energy need to refrigeration is the food and kindred products industry. In this sector, an estimated $50 \times 10^{12} \mathrm{Btu}$ for refrigeration could be supplied by geothermally driven absorption machines. The rest of the industrial sectors together might add another $100 \times 10^{12} \mathrm{Btu}(2 \%$ of the total industrial energy need for electrical drives) that could be provided by geothermal-powered refrigeration.

Process steam applications account for $10,132 \times$ $10^{12} \mathrm{Btu}$ of raw fuel consumption in the U.S. Most of this energy need could be satisfied by geothermal heating. Table 4 summarizes this author's estimate of the amounts and temperatures of steam used in each of the major industrial sectors. The table is based on data presented in a report by A.J. Miller, ${ }^{2}$ with modification based on analyses presented previously in this report. Total process steam used below $250^{\circ} \mathrm{C}$ is estimated to be about $9320 \times 10^{12} \mathrm{Btu}$, greater than $90 \%$ of all process steam used by U.S. industry.

Other Uses

The "other" energy-use category in Fig. 1 accounted for $4 \%$ of all energy used in the U.S. in 1968 (2464X $10^{12} \mathrm{Btu}$ ). Although this category includes a wide variety of energy applications, it consists primarily of lighting and electric appliances or motors; uses that cannot be met directly with geothermal energy.

*For more detailed descriptions of these groups, see Standard Industrial Classifications, Executive Office of the President, Bureau of the Budget. 
Table 3. Twenty major Standard Industrial Classification groups.*

Group

$20 \quad$ Food and Kindred Products

$21 \quad$ Tobacco Manufactures

22 Textile Mill Products

23 Apparel and Other Finished Products Made From Fabrics and Similar Materials

24 Lumber and Wood Products, Except Furniture

$25 \quad$ Furniture and Fixtures

26 Paper and Allied Products

27 Printing, Publishing, and Allied Industries

28 Chemicals and Allied Products

29 Petroleum Refining and Related Industries

$30 \quad$ Rubber and Miscellaneous Plastics Products

31 Leather and Leather Products

32 Stone, Clay, Glass, and Concrete Products

$33 \quad$ Primary Metal Industries

34 Fabricated Metal Products, Except Ordnance Machinery, and Transportation Equipment

35 Machinery, Except Electrical

36 Electrical Machinery, Equipment, and Supplies

37 Transportation Equipment

38 Professional, Scientific, and Controlling Instruments; Photographic and Optical Goods; Watches and Clocks

39

Title 
Table 4. Estimated uses of process steam (at various temperatures) in industrial sectors.

\begin{tabular}{|c|c|c|c|}
\hline Industry & $\begin{array}{c}\text { Temperature range } \\
\left({ }^{\circ} \mathrm{C}\right)\end{array}$ & $\begin{array}{l}\text { Total steam use } \\
\text { (\% of sector) }\end{array}$ & $\begin{array}{l}\text { Energy use } \\
\left(10^{12} \mathrm{Btu}\right)\end{array}$ \\
\hline Primary metals & $\geqslant 250$ & $\sim 100$ & 350.0 \\
\hline $\begin{array}{l}\text { Chemical and allied } \\
\text { products }\end{array}$ & $\begin{array}{r}\geqslant 250 \\
225-249 \\
200-224 \\
175-199 \\
150-174 \\
125-149\end{array}$ & $15 \%\left\{\begin{array}{r}5.0 \\
7.5 \\
7.5 \\
25 \\
25 \\
\frac{30}{100}\end{array}\right.$ & $\begin{array}{r}54.7 \\
82.0 \\
82.0 \\
273.5 \\
273.5 \\
328.2 \\
1093.9\end{array}$ \\
\hline Petroleum & $\begin{array}{l}225-249 \\
200-224 \\
175-199 \\
150-174 \\
125-149\end{array}$ & $20 \%\left\{\begin{array}{r}7 \\
7 \\
6 \\
40 \\
40 \\
\frac{100}{100}\end{array}\right.$ & $\begin{array}{r}67.2 \\
67.2 \\
57.6 \\
384.0 \\
384.0 \\
960.0\end{array}$ \\
\hline $\begin{array}{l}\text { Food and kindred } \\
\text { products }\end{array}$ & $\begin{array}{l}150-174 \\
125-149 \\
100-124\end{array}$ & $\begin{array}{r}10 \\
45 \\
45 \\
100\end{array}$ & $\begin{array}{r}90.0 \\
405.0 \\
405.0 \\
900.0\end{array}$ \\
\hline $\begin{array}{l}\text { Paper and allied } \\
\text { products }\end{array}$ & $\begin{array}{l}175-199 \\
150-174\end{array}$ & $\begin{array}{r}70 \\
30 \\
100\end{array}$ & $\begin{array}{r}703.5 \\
301.5 \\
1005.0\end{array}$ \\
\hline Other industries ${ }^{\mathrm{a}}$ & $\begin{array}{r}\geqslant 250 \\
225-249 \\
200-224 \\
175-199 \\
150-174 \\
125-149 \\
100-124 \\
75-99 \\
50-74\end{array}$ & $\begin{array}{r}7 \\
2 \\
2 \\
19 \\
19 \\
21 \\
7 \\
2 \\
21 \\
100\end{array}$ & $\begin{array}{r}407.6 \\
116.5 \\
116.5 \\
1106.4 \\
1106.4 \\
1222.8 \\
407.6 \\
116.5 \\
1222.8 \\
5823.1\end{array}$ \\
\hline
\end{tabular}

${ }^{a}$ Divided according to steam use in other categories, except for space heating component since all space heating appears in this category. Space heating is classified as heating in the 50 -to- $74^{\circ} \mathrm{C}$ temperature range. 


\section{DISCUSSION AND SUMMARY}

Based on the preceding discussion of energy consumption in the U.S., the energy-use categories in Fig. 1 are divided into "Potential Geothermal Use" and "Nongeothermal Use." The overall potential for direct application of geothermal energy is about $24,887 \times 10^{12} \mathrm{Btu}$, slightly greater than $40 \%$ of total U.S. energy use, assuming that appropriate geothermal resources are available at all application sites.

As explained, $250^{\circ} \mathrm{C}$ was set as the maximum temperature for direct geothermal application. It is useful, however, to consider geothermal applications below this maximum temperature. Figure 4 shows estimated energy use for heating in $25^{\circ} \mathrm{C}$ temperature ranges from 50 to $249^{\circ} \mathrm{C}$. Substantial amounts of the total energy is used even below $120^{\circ} \mathrm{C}$. In fact, space heating at 50 to $75^{\circ} \mathrm{C}$ is by far the largest single energy use at temperatures suitable for direct geothermal application, representing almost $50 \%$ of the total for temperatures below $250^{\circ} \mathrm{C}$. For comparison, Fig. 5 gives approximate required temperatures of geothermal fluids for various potential applications, as reported by Lindel. ${ }^{1}$

Figure 6 shows cumulative energy use at or below a certain temperature in relation to total U.S. energy consumption. This plot, constructed from the data in Fig. 4, shows total energy use based on the highest temperature in each $25^{\circ} \mathrm{C}$ range. Therefore, no energy use is shown below $74^{\circ} \mathrm{C}$. Notice that very little energy is required between 200 and $250^{\circ} \mathrm{C}$ and that the heating required below $200^{\circ} \mathrm{C}$ represents greater than $40 \%$ of total U.S. energy use and greater than $60 \%$ of energy consumed in the U.S. for purposes other than transportation and nonenergy applications.

It must be noted at this point, that although geothermal energy has the temperature necessary to be used directly in supplying process steam at somewhat reduced temperatures, it may not be desirable or wise to do so from an energy conservation point of view. Many industries using low-pressure steam get that steam either from processes such as ammonia synthesis or from high-pressure steam initially used to generate electricity or to drive steam turbines for direct mechanical drive. In the first case, there appears to be little incentive to switch to geothermal energy. In the second case, steam generation of electricity is a very good thermodynamic process and should not be replaced unless: (1) the energy supply gets so short that fossil fuels cannot be burned for heating and electricity must be supplied by nuclear or remote geothermal sources or (2) the geothermal resource can provide both electricity generation and steam requirements at the site. The chlorine-caustic soda and Solvay soda ash processes are good examples of the second case in that they both have substantial electrical and/or mechanical drive requirements and can get the process steam almost as a waste product from the electrical generation or mechanical drive. Almost all chlorine-caustic soda and Solvay soda ash plants produce their low-pressure steam in this manner.

In summary, of the total $60,526 \times 10^{12} \mathrm{Btu}$ consumed during 1968 in the U.S., greater than $40 \%$ could be supplied by geothermal resources at a temperature of $200^{\circ} \mathrm{C}$ or less, if the geothermal resource were available at each application site. About half of the $40 \%$ is space heating in industrial, residential, and commercial locations, which requires geothermal energy at less than $100^{\circ} \mathrm{C}$. Residential and commercial water heating also represents a substantial geothermal potential: $2389 \times 10^{12}$ Btu, which could be satisfied by geothermal energy at $100^{\circ} \mathrm{C}$. Similarly, air-conditioning accounts for $1540 \times 10^{12} \mathrm{Btu}$, which could be satisfied with geothermal energy at $125^{\circ} \mathrm{C}$ to $175^{\circ} \mathrm{C}$.

Large industrial processes that could use geothermal energy include:

- Chemical industry $\left(1094 \times 10^{12} \mathrm{Btu}\right)$ of which chlorine-caustic soda $\left(69 \times 10^{12} \mathrm{Btu}\right)$, Solvay soda ash $\left(57 \times 10^{12} \mathrm{Btu}\right)$, alumina $\left(52 \times 10^{12}\right.$ Btu), and Frasch-method sulfur mining $(\sim 60 \times$ $\left.10^{12} \mathrm{Btu}\right)$ are the largest potential users

- Paper and allied products industry (1005 $\times 10^{12}$ Btu)

- Food and kindred products industry $\left(900 \times 10^{12}\right.$ Btu)

- Petroleum refining industry $\left(960 \times 10^{12} \mathrm{Btu}\right)$. These industries could apply geothermal energy directly, however, because they all have large electrical requirements, competition with waste steam from electricity generation will be stiff. Individual case studies will be required before the potential substitution of geothermal energy in industry can be evaluated adequately. 


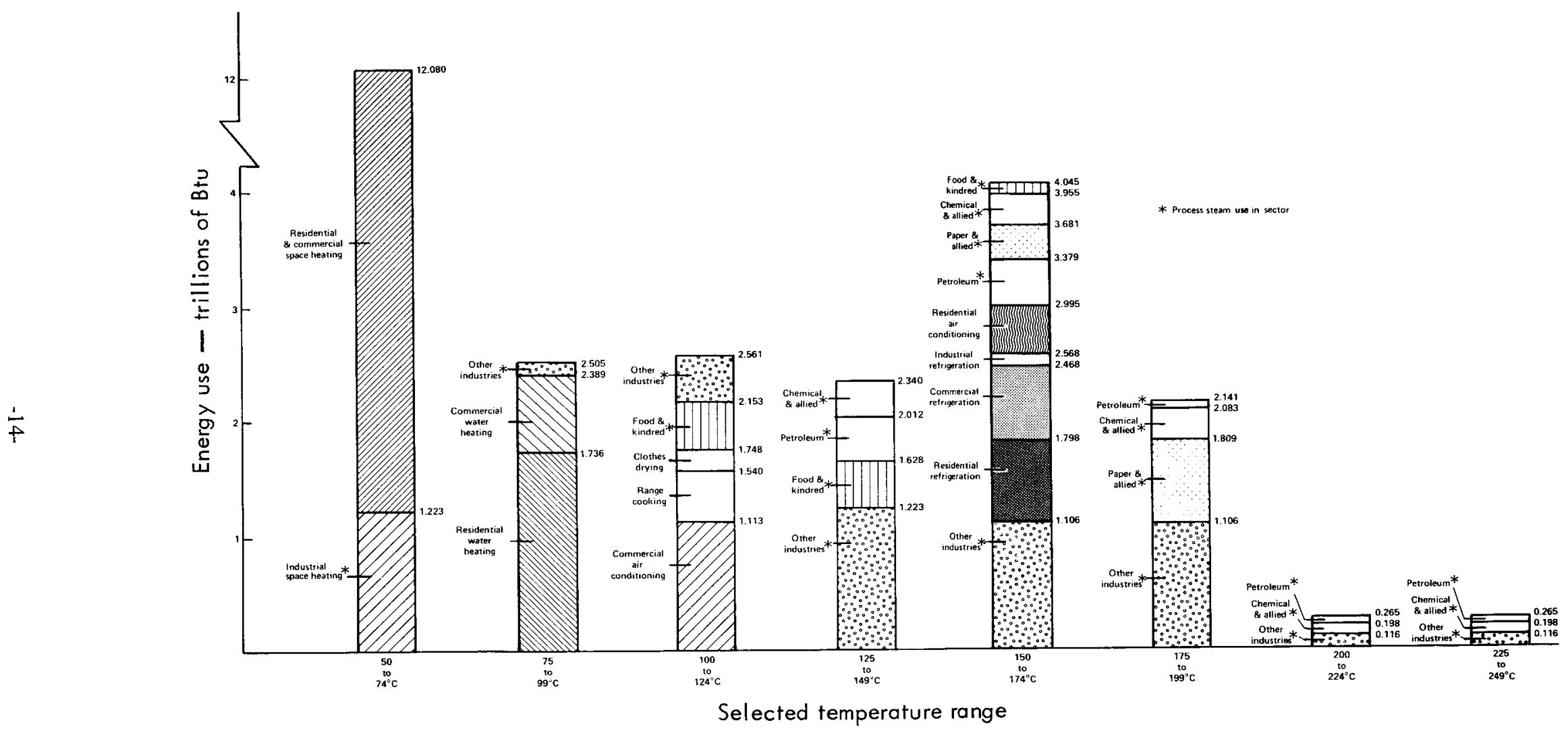

Fig. 4. Estimated heating energy use in selected $25^{\circ} \mathrm{C}$ temperature ranges. 


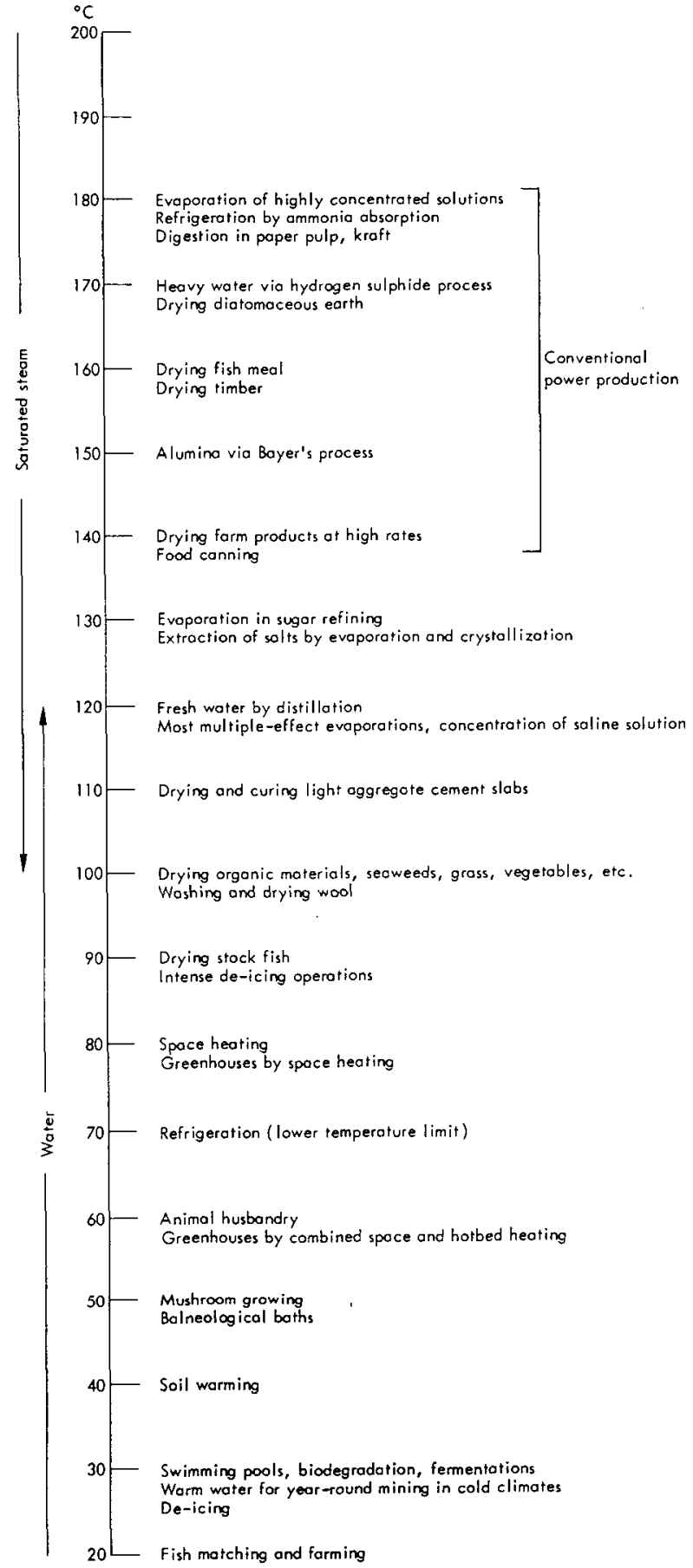

Fig. 5. Required temperatures (approximate) of geothermal fluids for various applications. Source: B. Lindal, "Industrial and Other Applications of Geothermal Energy," in Geothermal Energy: Review of Research and Development (1973). 


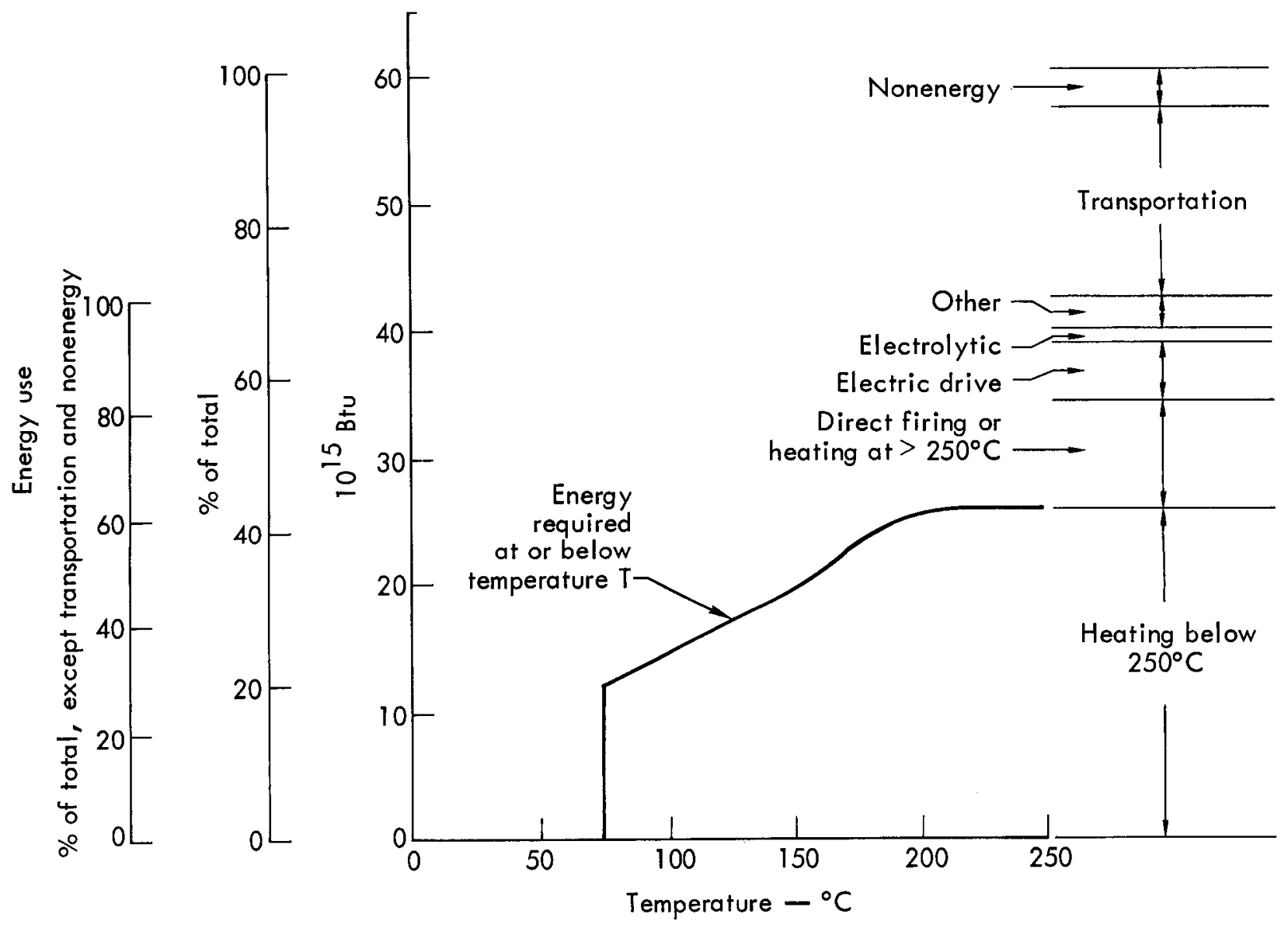

Fig. 6. Cumulative energy use, as a function of heating temperature, shown in relation to total U.S. energy requirements. 


\section{Energy-Cost-Intensive Industrial Uses of Geothermal Energy}

B. Lindal ${ }^{1}$ has presented a good treatment of the question, "What potential industrial uses of geothermal energy have steam costs as a significant enough portion of their total cost to motivate: (1) reinvesting in equipment, (2) relocating, and/or (3) developing new processing methods to allow utilization of geothermal energy?"* This section summarizes Lindal's findings. In addition, modifications of Lindal's thesis are presented in the in terest of completeness in covering potential nonelectric geothermal applications.

\section{STEAM REQUIREMENTS IN SELECTED INDUSTRIAL PROCESSES}

Table 5 shows Lindal's compilation of the steam requirements (in pounds of steam required per pound of product), product values (in cents per pound), and pounds of steam required per dollar product value (ratio of the first two items) for a number of established industrial processes. Lindal's basic premise is to use electric-power-consuming industries as a guide: here, the cost of electric power is a major consideration in plant location when it accounts for more than $10 \%$ of the value of the manufactured product. Thus, in steam-consuming industries, if steam costs amount to more than $10 \%$ of the value of the product, steam price should be a major consideration in plant location. Under these circumstances, the low price of geothermal steam may make it desirable to locate near a geothermal source. Using $\$ 1.75$ per ton for fuel-raised steam (an approximate, average cost of producing steam by fossil fuel in 1- to 2-MW power plants ${ }^{3}$ ) 10 of the 32 processes in Table 4 have steam costs greater than $10 \%$ of the product value. With the recent dramatic increase in fuel prices, the average cost of fuelraised steam is probably substantially more than $\$ 1.75$. Although product values no doubt have also increased due to inflation, probably more than 15 of the 32 processes listed now have steam costs amounting to $10 \%$ or more of product value and all but 9 of the processes probably have steam costs $5 \%$ or more of product value.

* Space heating, residential and commercial water heating, and residential and commercial air conditioning, although clearly energy cost intensive, are not further addressed in this study.
Only the 10 processes with the highest steam requirements per dollar product value are considered here regarding their potential for employing geothermal energy. These processes are listed in Table 6, in order of decreasing steam-to-dollar value.

Of these 10 processes, caustic soda, alumina, and soda ash production are large energy consumers and were treated in the previous section. Of the remaining processes, the distillation of fresh water from sea water and the production of heavy water by the hydrogen sulphide process have received considerable attention with regard to determining the potential for using geothermal energy as the prime energy source in these processes. There has been much discussion on the possibility of using geothermal energy in the production of fresh water from salt water. ${ }^{4-9}$ Distillation of fresh water from salt water is a well developed process, and geothermal energy certainly could be used in place of conventionally generated steam (assuming, of course, that the need for pure water and the geothermal resource are in coincident geographic locations). Also, the possibility of producing fresh water from the geothermal fluid itself looks promising because of the already high enthalpy of the liquid. This type of operation could also include mineral recovery. ${ }^{10}$

Use of geothermal energy in the production of heavy water has been considered for more than 20 years. Valfells ${ }^{11}$ emphasizes that, although there are several competitive processes, the hydrogen-sulphide water-isotope-exchange process is the most economical and, under favorable conditions, geothermal energy is substantially more desirable than other energy sources for this process.

If thorium-fueled nuclear power plants become widespread, the demand for heavy water will increase substantially, and there is a very good potential that much of it could be produced using geothermal energy.

The remaining five processes in Table 5 are considered in more detail in the following subsections.

\section{Acetic Acid from Wood Via Suida Process}

Only minor amounts of acetic acid are produced by wood distillation. Since the 1950 s, a growing proportion of the world's acetic acid has been produced from petroleum fractions by direct oxidation. Previously, 
Table 5. Steam consumption and steam use per dollar value in some established industrial processes. ${ }^{\mathbf{a}}$

\begin{tabular}{|c|c|c|c|}
\hline Product and process & $\begin{array}{c}\text { Steam } \\
\text { requirements } \\
\text { (lb steam/lb product) }\end{array}$ & $\begin{array}{l}\text { Product } \\
\text { value } \\
\text { (cents/lb) }\end{array}$ & $\begin{array}{l}\text { Steam per unit } \\
\text { product value } \\
\text { (lb steam } / \$ \text { value) }\end{array}$ \\
\hline Heavy water by hydrogen sulphide process & 10,000 & 3,000 & 333 \\
\hline Ascorbic acid & 250 & 250 & 100 \\
\hline Viscose rayon & $70^{\mathrm{b}}$ & 75 & 93 \\
\hline Lactose & 40 & 14 & 286 \\
\hline Acetic acid from wood via Suida process & 35 & 10 & 350 \\
\hline Ethyl alcohol from sulphite liquor & 22 & 7 & 314 \\
\hline Ethyl alcohol from wood waste & 19 & 7 & 271 \\
\hline Ethylene glycol via chlorohydrin & 13 & 13 & 100 \\
\hline Casein & 13 & 56 & 23 \\
\hline Ethylene oxide & 11 & 15 & 73 \\
\hline Basic $\mathrm{Mg}$ carbonate & 9 & 11 & 82 \\
\hline $35 \%$ hydrogen peroxide & 9 & 18 & 50 \\
\hline $85 \%$ hydrogen peroxide from $35 \% \mathrm{H}_{2} \mathrm{O}_{2}$ & $43 / 4$ & - & - \\
\hline Solid caustic soda via diaphragm cells & 8 & 3 & 266 \\
\hline Acetic acid from wood via solvent extraction & $71 / 2$ & 10 & 75 \\
\hline Alumina via Bayers process & $7^{\mathrm{c}}$ & 3 & 234 \\
\hline Ethyl alcohol from molasses & 7 & 7 & 100 \\
\hline Beet sugar & $53 / 4$ & 10 & 58 \\
\hline Sodium chlorate & $51 / 2$ & 9 & 61 \\
\hline Kraft pulp & $41 / 5$ & 6 & 70 \\
\hline Dissolving pulp & $41 / 5$ & - & - \\
\hline Sulphite pulp & $31 / 2$ & 6 & 58 \\
\hline Aluminium sulphate & $31 / 2$ & 2 & 175 \\
\hline Synthetic ethyl alcohol & 3 & 7 & 43 \\
\hline Calcium hypochloride, high test & $31 / 2$ & 3 & 111 \\
\hline Acetic acid from wood via Othmer process & $23 / 4$ & 10 & 28 \\
\hline Ammonium chloride & $23 / 4$ & 6 & 46 \\
\hline Boric acid & $21 / 4$ & 5 & 45 \\
\hline Soda ash via Solvay process & 2 & $11 / 2$ & 133 \\
\hline Cotton seed oil & 2 & 10 & 20 \\
\hline Natural sodium sulphate & $14 / 5$ & $11 / 2$ & 120 \\
\hline Cane sugar refining & $12 / 3$ & 10 & 17 \\
\hline Ammonium nitrate & $11 / 2$ & $31 / 2$ & 43 \\
\hline Ammonium sulphate & $1 / 6$ & $11 / 2$ & 11 \\
\hline Fresh water from sea water by distillation & $1 / 12$ & $1 / 60$ & 500 \\
\hline
\end{tabular}

aSource: B. Lindal, "Industrial and Other Applications of Geothermal Energy," in Geothermal Energy: Review of Research and Development (1973).

${ }^{\mathrm{b}}$ Shreve (1956) quotes $150 \mathrm{lb}$ steam per pound product.

${ }^{c}$ Has declined in recent years in most cases. 
Table 6. The ten most energy-cost-intensive industrial processes of Table 5 (in order of decreasing steam-to-dollar value).

1. Fresh water from sea water by distillation

2. Acetic acid from wood via Suida process

3. Heavy water by hydrogen sulphide process

4. Ethyl alcohol from sulphite liquor

5. Lactose production

6. Ethyl alcohol from wood waste

7. Solid caustic soda via diaphragm cells

8. Alumina via Bayers process

9. Aluminum sulphate production

10. Soda ash via Solvay process

acetic acid was produced primarily from acetaldehyde by dehydrogenation or oxidation. ${ }^{12}$

The Suida process is used in the U.S. and Europe to recover acetic acid directly from pyroligneous liquor, the product of destructive distillation of hardwoods. The Suida process uses steam for distillation and dehydration at temperatures from 125 to $175^{\circ} \mathrm{C}$. Therefore, geothermal energy could be substituted.

\section{Ethyl Alcohol from Sulphite Liquors}

Since the end of World War II, ethyl alcohol production from sulphite liquors has amounted to between 1 and $2 \%$ of the annual alcohol production in the U.S. ${ }^{13}$ However, in Sweden, all alcohol production, including beverage spirits (and, during WWII, alcohol for motor fuel) is based on waste sulphite liquors. ${ }^{14}$ In producing ethyl alcohol from the sulphite-liquor waste from wood pulp manufacture, steam is required in: steam stripping, the beer stills, and the final purifying process. This steam, required at saturation temperatures from 125 to $175^{\circ} \mathrm{C}$, could be generated using geothermal energy as the heat source.
Lactose Production

Production of lactose from skim milk, whey, and buttermilk requires steam for heating and drying. The maximum temperature used is about $150^{\circ} \mathrm{C}$, meaning geothermal energy could be readily used in this manufacturing process. Some $39,423,000$ pounds of lactose were produced in the U.S. during $1963 .^{15}$

\section{Ethyl Alcohol from Wood Waste}

Ethyl alcohol can be manufactured from sawdust by the Scholler process, the Bergius process, and a modified Scholler process developed at the U.S. Forest Products Laboratory in Madison, Wisconsin. A number of commercial plants using the Scholler process were built in Germany, Japan, Switzerland and Russia, however, only the Russian plants are still in operation. Except under special circumstances, producing ethyl alcohol from wood waste generally has proven to be uneconomical. ${ }^{16}$ In these processes, steam is required at saturation temperatures of 175 to $200^{\circ} \mathrm{C}$ for processing the wood with sulfuric acid and for processes 
similar to those used in the production of ethyl alcohol from sulphite liquor. Geothermal energy could meet these energy requirements.

Aluminum Sulphate

Aluminum sulphate is commonly marketed in two grades: commercial and iron-free. The commercial grade is produced from bauxite. Here, steam is required for digesting the finely-ground bauxite in sulfuric acid (at near the boiling point of the solution) and for evaporation in producing the solid aluminum sulphate. The steam is required at saturation temperatures from 125 to $175^{\circ} \mathrm{C}$. The iron-free grade is produced in a similar process, but here aluminum hydrate (a product of the Bayer process) replaces the bauxite. During 1960, about 900,000 short tons of aluminum sulphate were produced in the U.S. ${ }^{17}$ Again, geothermal energy could meet the energy needs for manufacturing this product.

\section{SUMMARY}

This section has presented Lindal's thesis ${ }^{1}$ that energy-cost-intensive processes using steam are the prime industrial candidates for nonelectrical applications of geothermal energy.* Of the ten most energy- cost-intensive processes considered, three were identified in the previous section of the report as being large energy users. All three of these processes (chlorine-caustic soda, synthetic soda ash, and alumina via Bayers process) are considered good possibilities for geothermal use. However, because of the large electrical requirements of these industries, much of their steam requirements can be generated quite efficiently and cheaply in a combined system with electricity generation. Consequently, a switch to geothermal energy would face very stiff conpetition in these industries. An earlier investigation ${ }^{18}$ of alumina production found that raw material and market conditions were unfavorable for an economic operation using geothermal energy. Two of the processes discussed, fresh water distillation and heavy water production have had considerable study with regard to potential geothermal use. Both have high potential for using geothermal energy.

The last five processes considered could use geothermal energy and would require it at less than $200^{\circ} \mathrm{C}$. Although there is presently little U.S. interest in three of the five processes (acetic acid via Suida process and ethyl alcohol from either sulphite liquor or wood waste), any anticipated production using any of these processes should consider geothermal energy as a potential source.

*As noted before, space-heating, residential and commercial water heating and residential and commercial air conditioning, although also prime candidates, were not addressed in this study. 


\section{Conclusion}

This analysis of potential nonelectrical applications of geothermal energy has focused on two fundamental questions. First, what are the major potential uses of geothermal energy in the U.S. economy? And second, what are the most energy-cost-intensive industrial uses of geothermal resources? Answers to the first question probably are of most use to national and regional planners. From their point of view, unless a potential use is of substantial magnitude, the expenditure of national or regional resources to develop the necessary technology and geothermal fields may not be justified. The second question addresses an important criteria at the initial stages of considering a potential process: if a process is very energy-cost intensive with respect to steam use, there is a good chance that the use of geothermal energy in the process will be economical. Of course, the location of the raw materials with respect to the geothermal resource is an important factor in process economics. On the other hand, if a process is not energy-cost intensive, it probably will not be a good candidate for geothermal use, unless energy consumption in the industry is very high and there is a quite good match in the location of the process, the raw materials, and the geothermal resource.
Certainly, the two aspects considered in this study, do not, by themselves, provide complete answers regarding potential nonelectrical uses of geothermal energy in the U.S. The energy-cost-intensiveness criteria merely indicates specific industrial processes that might merit additional consideration. The questions concerning the magnitude of potential geothermal energy uses and the potential for nonelectrical applications are only partially answered here because the relationship between resource and process locations was not considered in the analysis of potential.

Finally, extending this work to approximate the realizable potential for nonelectrical geothermal applications in the U.S., it is estimated that 20 to $40 \%$ of the total potential indicated in this analysis ( 10 to $20 \%$ of U.S. energy consumption) ultimately could be satisfied by geothermal energy. However, the next step in analyzing the potential for nonelectrical applications is to combine the concepts and data presented here with geothermal resource data and to evaluate what portion of the potential geothermal applications would or could be located near acceptable geothermal resources. 


\section{References}

1. B. Lindal, "Industrial and Other Applications of Geothermal Energy," in Geothermal Energy: Review of Research and Development (United Nations Education, Scientific, and Cultural Office, Paris, 1973; LC No. 72-97138), pp. 135-148.

2. A. J. Miller, H. R. Payne, M. E. Lackey, G. Samuels, M. T. Heath, E. W. Hagen, and A. W. Savolainen, Use of Steam-Electric Power Plants to Provide Thermal Energy to Urban Areas, Oak Ridge National Laboratory, TN, Rept. ORNL-HUD-14 (1971).

3. H. C. H. Armstead, "Geothermal Heat Costs," in Energy International (Brussels, 1969), p. 28.

4. G. Bodvarsson, "Utilization of Geothermal Energy for Heating Purposes and Combined Schemes Involving Power Generation, Heating, and/or By-products," in Proc. U.N. Conf. on New Sources of Energy, Rome, 1961 (United Nations, New York, 1964), Paper GR/5(G), vol. 3, part II, pp. 429-436.

5. H. C. H. Armstead, "The Extraction of Power from Hot Water," in Proc. World Power Conf., 1967 (Moscow, 1968), sect. E4, p. 174.

6. R. W. Rex, Investigation of the Geothermal Potential of the Lower Colorado River Basin, Phase 1 - The Imperial Valley Project, Institute of Geophysics and Planetary Physics, University of California, Riverside, CA (1968).

7. R. W. Rex, "Geothermal Resources in the Imperial Valley," in California Water - A Study in Resource Management, D. Seckler, Ed. (Berkeley Press, University of California, Berkeley, CA, 197I), p. 348.

8. C. M. Wong, "Geothermal Energy and Desalination - Partners in Progress," in Geothermics, Special Issue 2 (Pisa, Iatly, 1970), vol. 2, part 1, pp. 892-895.

9. J. Barnea, "Multipurpose Exploration and Development of Geothermal Resources," in Proc. Natural Resources Forum, 1971 (United Nations, New York, 1971), vol. 1, no. 1, pp. 55-58.

10. H. H. Werner, "Contribution to the Mineral Extraction from Supersaturated Geothermal Brines, Salton Sea Area, California," in Geothermics, Special Issue 2 (Pisa, Italy, 1970), vol. 2, part 2, pp. 1651-1657.

11. A. Valfells, "Heavy Water Production with Geothermal Energy," in Geothermics, Special Issue 2 (Pisa, Italy, 1970), vol. 2, part 1, pp. 896-900.

12. R. E. Kirk and D. F. Othmer, Eds., "Ethanoic Acid," in Encyclopedia of Chemical Technology (Interscience Publishers, New York, 1965), 2nd ed., vol. 8, pp. 386-421.

13. R. E. Kirk and D. F. Othmer, Eds., "Ethanol," in Encyclopedia of Chemical Technology (Interscience Publishers, New York, 1965), 2nd ed., vol. 8, pp. 422ff.

14. R. N. Shreve, Chemical Process Industries (McGraw Hill, New York, 1967), 3rd ed., p. 61.

15. R. E. Kirk and D. F. Othmer, Eds., "Sodium Carbonate," in Encyclopedia of Chemical Technology (Interscience Publishers, New York, 1969), 2nd ed., vol. 18, pp. 458-468.

16. R. E. Kirk and D. F. Othmer, Eds., "Wood," in Encyclopedia of Chemical Technology (Interscience Publishers, New York, 1970), 2nd ed., vol. 22, p. 383.

17. R. E. Kirk and D. F. Othmer, Eds., "Aluminum Compounds," in Encyclopedia of Chemical Technology (Interscience Publishers, New York, 1963), 2nd ed., vol. 2, p. 61.

18. B. Lindal, "Geothermal Heating for Industrial Purposes in Iceland," in Proc. U.N. Conf. on New Sources of Energy, Rome, 1961 (United Nations, New York, 1964), Paper G/59, vol. 3, part II, pp. 429-436. 


\section{Appendix}

\section{Major Applications of Geothermal Energy in the Chemical and Allied Products Industries}

Chlorine-Caustic Soda

About $75 \%$ of all U.S. chlorine and caustic soda production is by electrolytic methods using diaphragm cells. Figure A-1 shows a flow diagram of a typical diaphragm-cell process for producing caustic soda (76\% caustic) and chlorine. The major energy requirements in this process ( 80 to $90 \%$ ) are electricity for electrolysis and steam for evaporation. Additional energy ( 10 to $20 \%$ ) is required for pumps, compressors, and refrigeration for liquified chlorine. The temperatures and specific amounts of steam depend on the type of caustic produced. Normal $50 \%$ caustic is produced in double- or triple-effect evaporators, which require steam at 50 to 60 psig for the first stage.

Stronger, 70 to $75 \%$ caustic can be concentrated from cooled and settled $50 \%$ caustic in a single-effect, final evaporator, requiring at least 75 to 100 psig steam. Also, caustic containing less than $1 \%$ water can be produced by finishing 50 or $75 \%$ caustic in Dow therm heated evaporators or direct-fired units at temperatures of 450 to $600^{\circ} \mathrm{C}$. Since most of the volume in the industry is $50 \%$ caustic followed by 70 to $75 \%$ caustic, most of the $69 \times 10^{12} \mathrm{Btu}$ of steam required by the industry could be supplied using geothermal energy at a maximum temperature of $170^{\circ} \mathrm{C}$.

Because of the low temperatures involved (less than $0^{\circ} \mathrm{C}$ ) refrigeration requirements in this industry probably could not be met with geothermal energy. The ammonia-water system would have to be used. This would pose many operating problems associated with using ammonia in vacuum. More important, if the ammonia and chlorine should ever come in contact with each other, they would form a very explosive mixture, a risk probably too great to warrant the use of this type of refrigeration system.

\section{Synthetic Soda Ash}

Synthetic soda ash is sodium carbonate produced by the Solvay (ammonia-soda) process. Production of synthetic soda ash has been limited by an increasing shift to natural soda ash derived from trona (sodium sesquicarbonate). Nonetheless, the synthetic process still consumes tremendous amounts of energy and remains potentially important on a national and worldwide basis. A flowchart of the Solvay process is shown in Fig. A-2. The process requires energy for a variety of purposes: kilning requires coke for burning with limestone; steam is required in the weak-and strong-liquor stills; energy is required in the calciner (older units being direct fired, modern units using steam); and substantial amounts of energy are required for various pumping, compressing, and milling tasks. The calciner, which uses steam at about $235^{\circ} \mathrm{C}$, accounts for roughly 40 to $50 \%$ of the total energy requirement for soda ash production, excluding the coke requirement. Steam for the stills (at about $120^{\circ} \mathrm{C}$ ) comprises 35 to $45 \%$ of the energy requirement, and mechanical drives account for the remaining 15 to $20 \%$ of the total energy demand. ${ }^{\mathrm{A} 1}$ At these temperatures, geothermal energy at $235^{\circ} \mathrm{C}$ could satisfy 40 to $50 \%$ of the industry's steam requirements and at $120^{\circ} \mathrm{C}$ could meet 35 to $45 \%$ of the requirements.

\section{Ammonia}

Ammonia production consumes very large amounts of steam, but has little potential for direct geothermal applications because of the high steam temperatures required $\left(775^{\circ} \mathrm{C}\right.$ for reforming $\mathrm{CH}_{4}$ and $400^{\circ} \mathrm{C}$ for the shift conversion). In addition, ammonia production, being a highly exothermic process, provides enough byproduct thermal energy to generate steam economically.

Alumina

Almost all alumina produced in the world is extracted from bauxite via the Bayer process. A flow diagram of the Bayer process is shown in Fig. A-3. The major energy inputs are steam for dissolving the alumina, steam for evaporation, and fuel for calcination. The calcination process takes place at very high temperatures (about $1200^{\circ} \mathrm{C}$ ) and, therefore, cannot use geothermal energy. However, the steam used in the Bayer process cound be supplied by geothermal energy. The steam used for evaporation must be between $120^{\circ} \mathrm{C}$ and $150^{\circ} \mathrm{C}$. In the dissolving of alumina, two techniques 


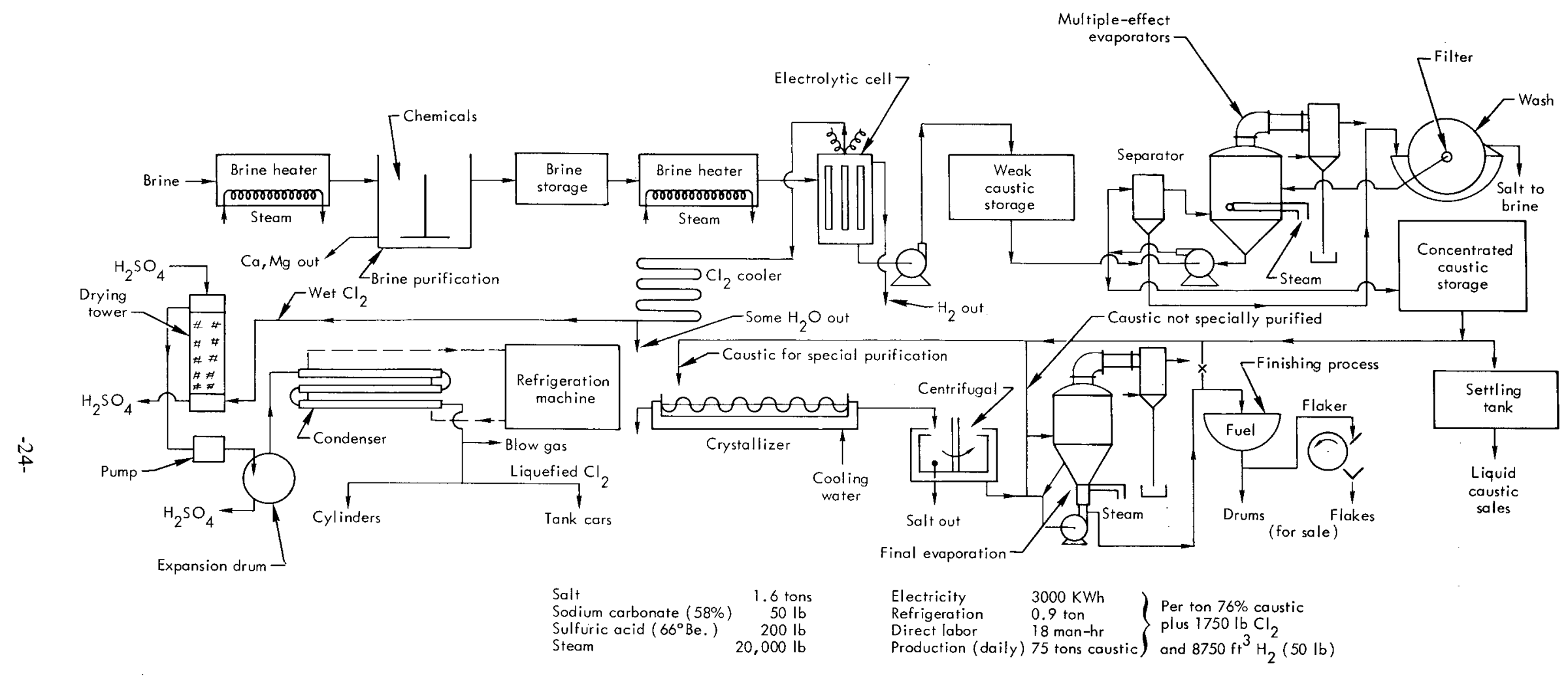

Fig. A-1. Flowchart of diaphragm caustic soda and chlorine cell. Source: R.N. Shreve, Chemical Process Industries, 3rd ed. (1967). 


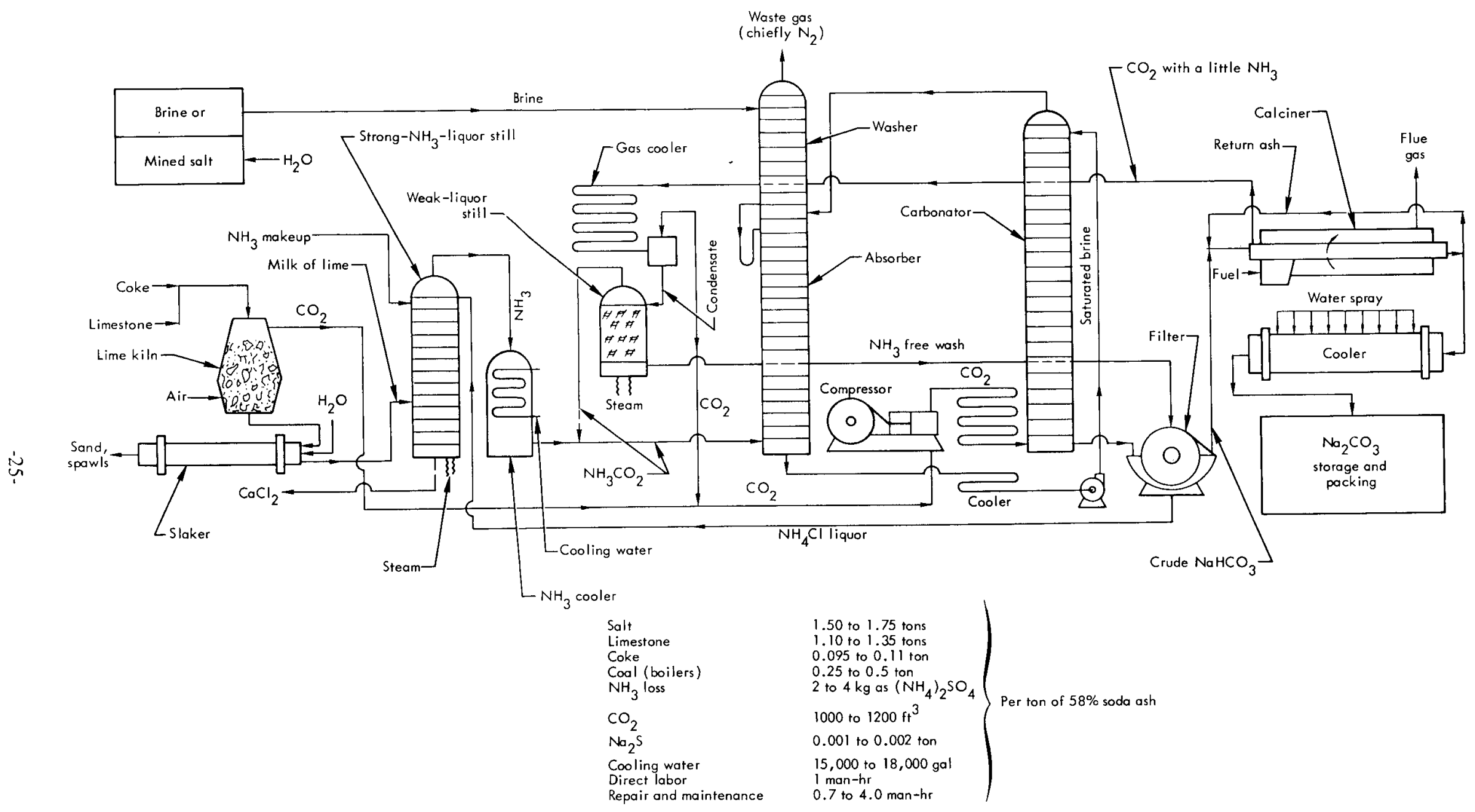

Fig. A-2. Soda ash manufacture by ammonia-soda process. Source: R.N. Shreve, Chemical Process Industries, 3rd ed. (1967). 


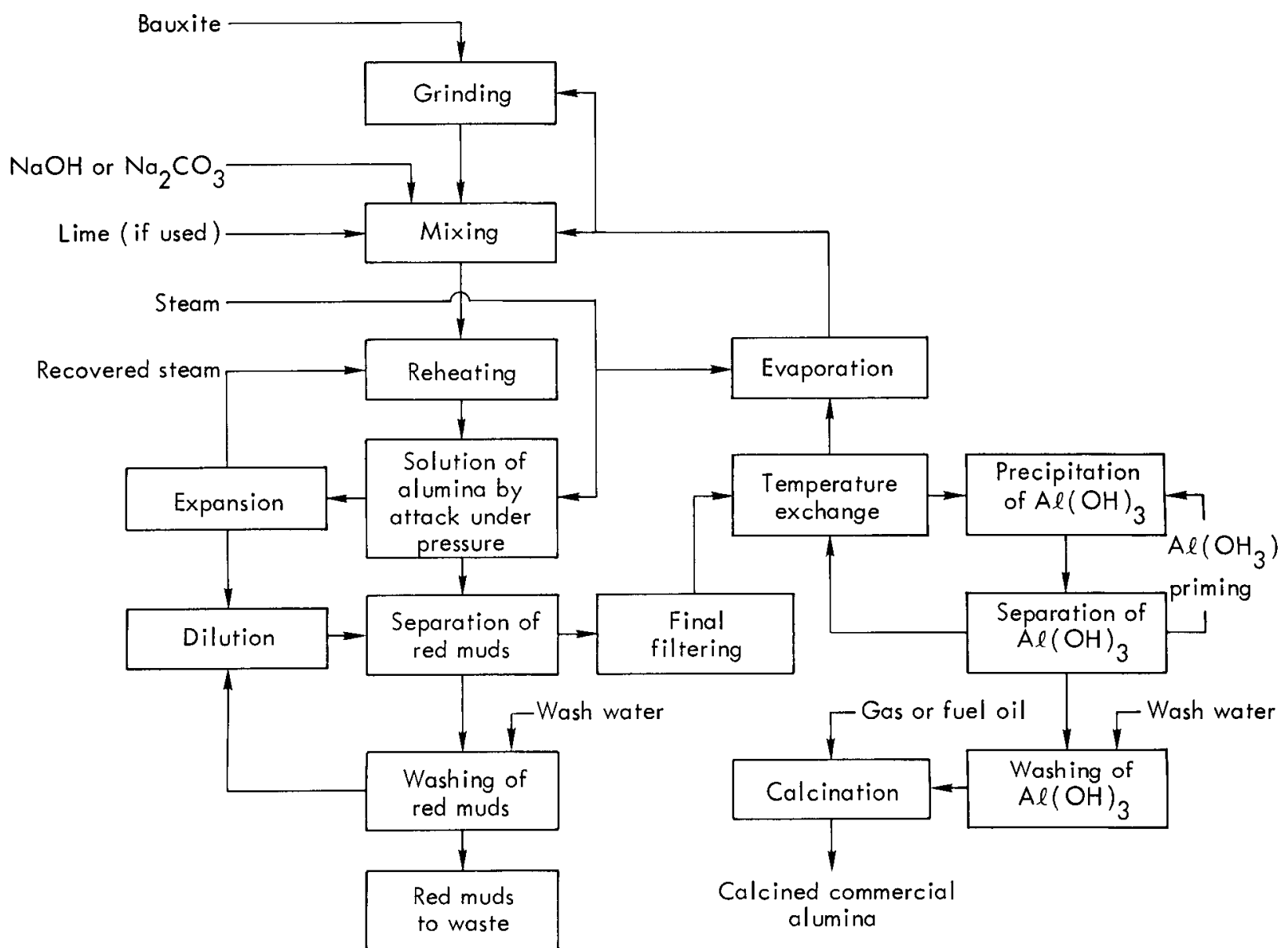

Fig. A-3. Alumina production from bauxite by the Bayer process. Source: R.E. Kirk and D. F. Othmer, Eds., Encyclopedia of Chemical Technology (1963).

are used, the European and American methods, each having different steam requirements. In the European method, high concentrations of caustic soda and temperatures of 200 to $250^{\circ} \mathrm{C}$ are required to process European bauxites, which contain boehmite. In the American process, lighter concentrations of caustic soda and corresponding lower temperatures (between 120 and $140^{\circ} \mathrm{C}$ ) are needed to deal with the trihydrated tropical bauxites used. However, recent use of Jamaican bauxites, which contain some boehmite, have necessitated the high-concentration, high-temperature treatment typical in Europe.

Most of the $52 \times 10^{12}$ Btu consumed in the U.S. alumina industry could be supplied geothermally. Geothermal energy at $150^{\circ} \mathrm{C}$ could satisfy the industry's steam requirements, except for bauxite con- taining boehmite. Boelımite-bearing bauxite would require a geothermal temperature of $250^{\circ} \mathrm{C}$.

Methanol

The most important method of manufacturing methanol is by a medium-pressure process using hydrogen, carbon monoxide, and small amounts of carbon dioxide. This mixture of gases, called "synthesis gas" is produced in the U.S. primarily from coke and natural gas. Although methanol manufacture uses steam (mainly in "synthesis gas" production), the uses are at a quite high temperature (e.g., 300 to $500^{\circ} \mathrm{C}$ for the water-gas shift reaction and $875^{\circ} \mathrm{C}$ for natural gas conversion). Therefore, application of geothermal energy does not appear feasible. 


\section{Sulfur (Frasch)}

Sulfur mining by the Frasch method provides a major but decreasing percentage of all elemental sulfur produced in this country. The Frasch process appears to have very good potential for geothermal application. In this method, $165^{\circ} \mathrm{C}$ water is pumped under pressure down into a deposit to melt the sulfur. The melted sulfur is then brought to the surface using a combination of air lift and hydraulic pressures. Some 40 to 50 tons of hot water are required per ton of mined sulfur. Energy is also required for driving pumps and compressors, for miscellaneous electrical uses, and for steam-heating the sulfur lines from the borehole. Present practice is set up so that about $25 \%$ of the water for mining is converted to high-pressure steam, which when exhausted from the primemover, is re-used to preheat mining water.

\section{Other Processes}

Other processes in the chemical industry (see Table 1 in this report) appear to have relatively little direct geothermal potential, in that their major energy consumptions are either mechanical drives or feedstock.

\section{REFERENCE}

A1. R. E. Kirk and D. F. Othmer, Eds., "Sodium Carbonate," in Encyclopedia of Chemical Technology (Interscience Publishers, New York, 1969), 2nd ed., vol. 18, pp. 458-468. 